\section{Summary points}

Trichotillomania is an "impulse-control disorder" in humans, characterised by repetitive stereotypical hair pulling from different areas

Barbering in mice can serve as an animal model of trichotillomania

Mice homozygous for a loss of function mutation in Hoxb8 gene (involved in grooming behaviour) display clinical signs of trichotillomania

Studies are needed to see if people with trichotillomania have the same mutation and whether prescription drugs that ameliorate trichotillomania can cut back grooming in Hoxb8 mice

and human pathologies are similar. Trichotillomania may arise as a result of the misregulation of an innate self grooming behaviour that results in excessive repetition. It would be interesting to find out whether subsets of human patients with trichotillomania have defects in the Hoxb8 gene or in the paralogous family members Hoxc8 and Hoxd8.

We thank Judith A James for supplying the mice shown in the photograph and Yaser Dorri for his help with the photography. Contributors: Animal immunisation studies were carried out by BTK and RHS with TG's assistance. The manuscript was written by BTK and approved by RHS and TG.

Funding: This work was supported by NIH grant ARO1844 awarded to RHS and by funding from the Oklahoma Center for the Advancement of Science and Technology to RHS and BTK. Competing interests: None declared.

Ethical approval: The animal immunisation experiments described in the manuscript were approved by the Institutional Review Board.
1 Scofield RH, Henry WE, Kurien BT, James JA, Harley JB. Immunization with short peptides from the sequence of the systemic lupus erythematosus-associated 60-kDa Ro autoantigen results in anti-Ro ribonucleoprotein autoimmunity. J Immunol 1996;156:4059-66.

2 Scofield RH, Kaufman KM, Baber U, James JA, Harley JB, Kurien BT. Immunization of mice with human 60-kd Ro peptides results in epitope spreading if the peptides are highly homologous between human and mouse. Arthritis Rheum 1999:42:1017-24.

3 Scofield RH, Pierce PG, James JA, Kaufman KM, Kurien BT. Immunization with peptides from $60 \mathrm{kDa}$ Ro in diverse mouse strains. Scand J Immunol 2002;56:477-83.

4 Bresnahan JF, Kitchell BB, Wildman MF. Facial hair barbering in rats. Lab Anim Sci 1983;33:290-1.

5 Sarna JR, Dyck RH, Whishaw IQ. The Dalila effect: C57BL6 mice barber whiskers by plucking. Behav Brain Res 2000;108:39-45.

6 Strozik E, Festing MF. Whisker trimming in mice. Lab Anim 1981;15:30912.

7 Van den Broek FA, Omtzigt CM, Beynen AC. Whisker trimming behaviour in A2G mice is not prevented by offering means of withdrawal from it. Lab Anim 1993;27:270-2.

8 Garner JP, Weisker SM, Dufour B, Mench JA. Barbering (fur and whisker trimming) by laboratory mice as a model of human trichotillomania and obsessive-compulsive spectrum disorders. Comp Med 2004;54:216-24.

9 Ordnick PS, Thyer BA, Ritchie BW. Feather picking disorder and trichotillomania: an avian model of human psychopathology. J Behav Ther Exp Psychiatry 1994;25:189-96.

10 Reilly CE. Disruption of Hoxb8 gene leads to obsessive grooming behavior. J Neurol 2002;249:499-501.

11 Stein DJ, Simeon D, Cohen LJ, Hollander E. Trichotillomania and obsessive-compulsive disorder. J Clin Psychiatry 1995;56(suppl 4):28-34

12 Lochner C, Seedat S, du Toit PL, Nel DG, Niehaus DJ, Sandler R, et al. Obsessive-compulsive disorder and trichotillomania: a phenomenological comparison. BMC Psychiatry 2005;5:2.

13 Swedo SE, Leonard HL, Rapoport JL. Childhood-onset obsessive compulsive disorder. Psychiatr Clin North Am 1992;15:767-75.

14 Alsafwah S, Alzein M. Small bowel obstruction due to trichobezoar: role of upper endoscopy in diagnosis. Gastrointest Endosc 2000;52:784-6.

15 Diagnostic and statistical manual of mental disorders. 4 th ed. Washington DC: American Psychiatric Press, 1994:618.

16 O'Sullivan RL, Mansueto CS, Lerner EA, Miguel EC. Characterization of trichotillomania. A phenomenological model with clinical relevance to obsessive-compulsive spectrum disorders. Psychiatr Clin North Am 2000;23:
o 587-604.

17 Simeon D, Cohen LJ, Stein DJ, Schmeidler J, Spadaccini E, Hollander E. Comorbid self-injurious behaviors in 71 female hair-pullers: a survey study. J Nerv Ment Dis 1997;185:117-9.

18 Bouwer C, Stein DJ. Trichobezoars in trichotillomania: case report and literature overview. Psychosom Med 1998;60:658-60.

19 Wright HH, Holmes GR. Trichotillomania (hair pulling) in toddlers. Psychol Rep 2003;92:228-30.

20 Greer JM, Capecchi MR. Hoxb8 is required for normal grooming behavior in mice. Neuron 2002;33:23-34.

21 Du Toit PL, van Kradenburg J, Niehaus DJ, Stein DJ. Characteristics and phenomenology of hair-pulling: an exploration of subtypes. Compr Psychiatry 2001;42:247-56.

\title{
Harry Potter casts a spell on accident prone children
}

\author{
Stephen Gwilym, Dominic P J Howard, Nev Davies, Keith Willett
}

In the infancy of this millennium two things are certain: children injure themselves on the latest "craze" and children will (probably) read the Harry Potter books. Previous reports have highlighted the impact of emerging crazes such as inline skating and microscooters, with attention being drawn to potential accident prevention and emerging patterns of injury.

One modern craze is the Harry Potter series of books and films. In the United Kingdom sales of the latest Harry Potter book, The Half-Blood Prince, are estimated to reach four million, with around three million volumes being sold in the first week.

Given the lack of horizontal velocity, height, wheels, or sharp edges associated with this particular craze we were interested to investigate the impact the Harry Potter books had on children's traumatic injuries during the peak of their use.

\section{Methods and results}

We undertook a retrospective review of all children aged 7-15 who attended our emergency department with musculoskeletal injuries over the summer months of a three year period. Weekend admissions were counted as those occurring between 8 am on Saturday and 8 am on Monday. The age range was based on that of reading competence on the advice of an educationalist.

The launch dates of the two most recent Harry Potter books-The Order of the Phoenix ${ }^{1}$ and The Half-Blood Prince ${ }^{2}$-were Saturday 21 June 2003 and Saturday 16 July 2005 . We compared the numbers of admissions for these weekends with those for surrounding summer weekends and those dates in previous years.
Department of Orthopaedic Trauma Surgery, John Radcliffe Hospital, Oxford OX3 9DU Stephen Gwilym specialist registrar Dominic P J Howard senior house officer Nev Davies specialist registrar Keith Willett consultant

Correspondence to: S Gwilym s_gwilym@ yahoo.com

BMJ 2005;331:1505-6 


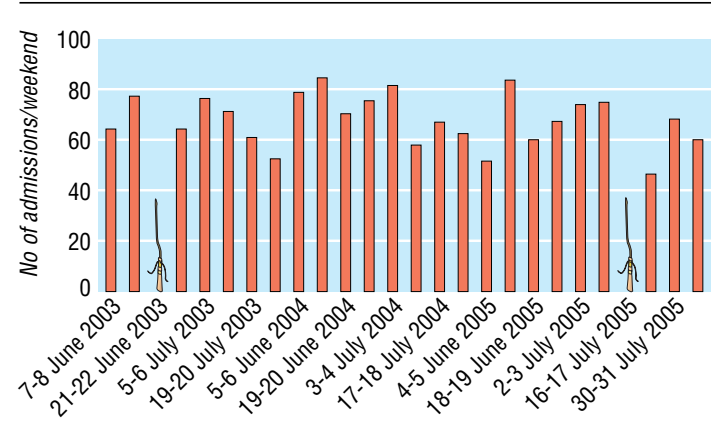

Note: Firebolt brooms indicate the two weekends when the latest Harry Potter books were released Children attending emergency department with musculoskeletal injuries on summer weekends 2003-5

We obtained data from the MetOffice ${ }^{3}$ (www.metoffice.gov.uk) to establish weather conditions recorded for each of the identified weekends at the closest weather station (Brize Norton) to our hospital. This allowed us to adjust for weather as a confounding variable if necessary.

The figure shows the weekend attendance to our emergency department in June and July between 2003 and 2005. The mean attendance rate for children aged 7-15 years during the control weekends was 67.4 (SD 10.4). For the two intervention weekends the attendance rates were 36 and 37 (mean 36.5, SD 0.7). This represents a significant decrease in attendances on the intervention weekends, as both are greater than two SD from the mean control attendance rate and an unpaired $t$ test gives a $t$ value of $14.2(\mathrm{P}<0.0001)$. At no

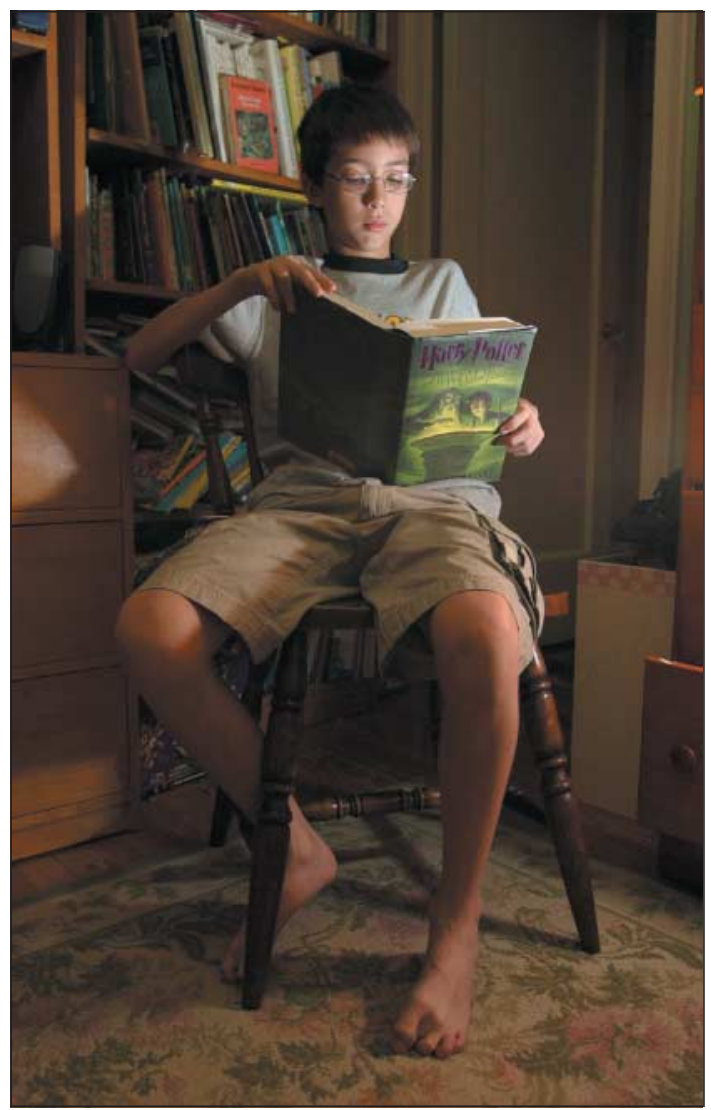

\section{What is already known on this topic}

Traumatic childhood injuries are a serious source of mortality and morbidity

There is a seasonal variation in the incidence of injuries in muggle children, with the highest numbers occurring during periods of longest daylight, warm weather, and school holidays

\section{What this study adds}

Releasing Harry Potter books seems to reduce the incidence of traumatic injuries in children

other point during the three year surveillance period was attendance that low. MetOffice data suggested no confounding effect of weather conditions.

\section{Comment}

Harry Potter books seem to protect children from traumatic injuries. Fashionable or "craze" activities have previously undoubtedly contributed to the two million children who attend emergency departments with traumatic injuries each year. Organisations such as the Child Accident Prevention trust (www. capt.org.uk) and Royal Society for the Prevention of Accidents (www.rospa.org.uk) have yet to recognise the potential benefit of this new pursuit.

To date no research has addressed the option of "distraction therapy" to prevent traumatic injuries. Alternative strategies such as "restraint therapy" and "pharmacological modification" have been considered and abandoned on ethical grounds. Distraction therapy has been used successfully in settings such as painful clinical procedures with good effect.

We observed a significant fall in the numbers of attendees to the emergency department on the weekends that of the two most recent Harry Potter books were released. Both these weekends were in mid-summer with good weather. It may therefore be hypothesised that there is a place for a committee of safety conscious, talented writers who could produce high quality books for the purpose of injury prevention.

Potential problems with this project would include an unpredictable increase in childhood obesity, rickets, and loss of cardiovascular fitness.

Contributors: KW conjured up the original idea for the work having experienced a quiet on-call weekend, then witnessing three of his children "petrified" on the sofa. DPJH and ND are wizards with numbers. SG wrote the paper and performed a spell check. DPJH is guarantor.

Funding: None.

Competing interests: KW has five children and has spent many summer days in the emergency department. SG, DPJH, and ND have no children but each have a pet owl.

Ethical approval: Not required.

Rowling JK. Harry Potter and the order of the phoenix. London: Bloomsbury, 2003.

Rowling JK. Harry Potter and the half-blood prince. London: Bloomsbury, 2005.

The Met office. www.met-office.gov.uk (accessed 4 Sep 2005).

(Accepted 22 November 2005) 